\title{
A conversation with Tony Fauci
}

T ony Fauci is the Director of the National Institute of Allergy and Infectious Diseases within the National Institutes of Health. His work on HIV is at the forefront of infectious disease research, and he is the leader of the national discussion of infectious disease pandemics - the science behind them, the economy, the policy, and the politics that are also intertwined with them. The full interview with Dr. Fauci (Figure 1), including kernels of his advice (in Latin) and how to get along with Presidents and confrontative activists alike can be seen on the JCI website, http://www.jci. org/kiosk/cgm.

JCI: What were you like as a kid?

Fauci: My grandparents were born in Italy and did what so many immigrants did, arrived in New York City, lived for a little bit in Little Italy in Manhattan, moved to Brooklyn, where my mother and father lived essentially their entire life. It was a very nurturing atmosphere with a lot of family values, community appreciation, friends, and some tough knocks. Growing up in the streets of New York City is sometimes not the easiest thing in the world and certainly challenging for a young child. You learn to be resourceful, to protect yourself, to be fair, and not take much guff from anybody. I was very into sports. I did well in school and enjoyed it. I went to an elementary school in Brooklyn, but one of the things that had a particularly important impact on me is that I went to an elite Jesuit-run school in Manhattan, Regis High School. It was a total scholarship school, highly competitive to get into from all of the five boroughs, including people from New Jersey and other places, so we had quite a highly motivated class.

JCI: When was your interest in science first cultivated?

Fauci: It started in high school, but I was very attracted, through the influence of the Jesuit way of teaching, to the humanities and the classics. When I started to take science courses in high school, I realized that I was fascinated by science, by discovery, knowledge, and the rational approach to problems. It seemed to me that being a physician was the perfect melding of science and being involved deeply with people, something that I still maintain to the present time in my role as a physician. By the time I finished high school, I went to college wanting to be a physician.

JCI: While you were in college, you spent some summers back in the city, working construction, including on the library at Cornell Medical School.

Fauci: I had in my mind the idea that I would want to come back to New York City and go to Cornell. During college, I worked summers on construction gangs.

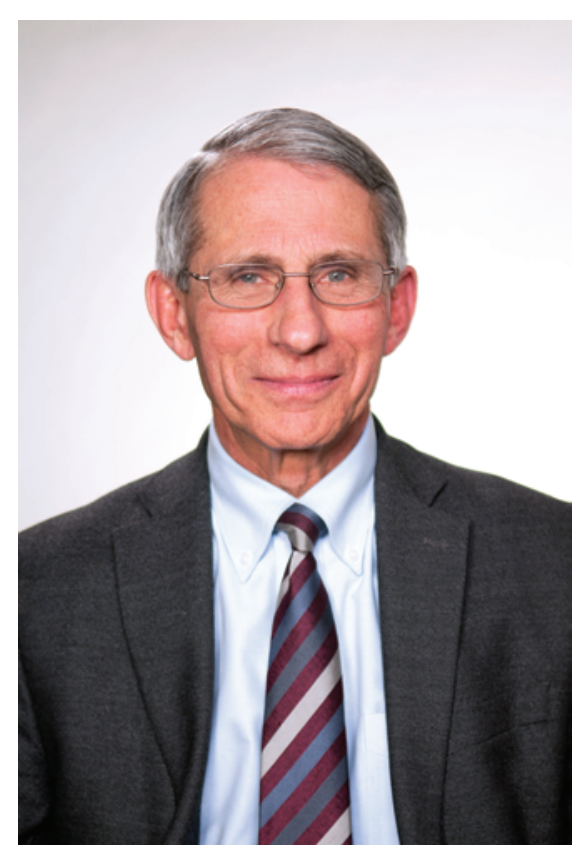

Figure 1

Tony Fauci on April 26, 2014. Image credit: Karen Guth.

One summer I worked on the construction of the Cornell Medical School Library. And so it was very interesting because for the years that I was there as a medical student, intern, resident, chief resident, as I would walk by the street, I would remember sitting there with my construction boots and my hat and my sunglasses, pushing a wheelbarrow. I've seen it all the way through.

The spirit and the atmosphere of collegiality really created a very warm feeling about medicine in general. I think it's one of the greatest places you could imagine. I was heavily steeped in wanting to be a physician. I loved taking care of patients: the sicker, the better. I did a research project as an elective in my third year, and I started to see how interesting it is to ask a scientific question, but I kind of put it in the back of my mind. What I really wanted to do was to get involved in this new burgeoning field of the interface between immunology and infectious diseases. And at the time, the Vietnam War was on and all doctors were drafted, and you could either go into the Army, the Air Force, the Navy, or the Public Health Service (the NIH or the CDC). As it turns out, I got into the NIH. When I got down to the NIH, I really became quite enamored of the scientific method, asking the question, getting an answer, analyzing data. That began what I'm still doing now, essentially a lifelong career in research that's very closely interdigitated with clinical medicine.

JCI: What is it about the NIH that has kept you so engaged and devoted?

Fauci: It's an electrifying place. It's an extraordinary critical mass of very smart, very collegial people with a wide range of expertise. You don't have to walk very far to find somebody who is the world expert in a particular area that you're interested in.

The Clinical Center was a major attracting force for me when I started. I spent many years studying vasculitis patients there, and we developed the treatments for Wegener's granulomatosis and polyarteritis nodosa, and then when HIV came in 1981, I made a dramatic shift in my career and began admitting patients with this strange disease. That ability to turn on a dime and ask a question was extremely attractive to me, and the attraction still remains.

JCI: What was it that made you choose to study HIV?

Fauci: In 1981, when the first reports of severely ill gay men came in from Los Angeles, New York, and San Francisco, I remember thinking, "This is a new disease and it's clearly an infection. We don't know what it is. It's destroying the immune system, so who better than someone who's an immunology/infectious disease scientist to study this?" That's when I essentially stopped what I had been doing and started bringing in HIV-infected individuals. I remember my mentors looking at me, saying, "Why are you doing this? You're throwing away a potentially great career." And I said, "No, no, no. This is going to really be big. Trust me." 
I describe that time as the dark years of my professional career because every one of my patients died. I brought in hundreds of patients during those early years. The median survival was six to eight months at the time, and we didn't even know what the virus was and we certainly didn't have any therapies.

It was a terrible feeling on a day-by-day basis, but every time you made another scientific observation, it was new. We started off studying pathogenesis before we even knew what the virus was. One of my first papers on HIV described the aberrant immune activation - the paradox of an immunodeficiency disease in which the immune system was aberrantly turned on. I had no idea what that meant. As it turns out, you fast forward 15 years when we really got our arms around things, when we had the virus, and we could treat people and bring the virus from half a million copies down to less than 40 copies, that immune activation is actually the driving force of HIV replication. So it's a paradox that the virus turns on the immune system, activates it, and the very activation is the thing that drives virus replication.

I think it's one of the most extraordinary success stories in the history of medicine. We went from not even knowing what the virus was to knowing what it is, developing drugs from AZT, approved in 1987, to 1996 when we had the triple combinations. Now that same patient whom I described -20 plus years old and recently infected - if I start the patient on triple combination, which you can now get in one single pill taken once a day, you could project that person, if they take their medicines faithfully, could live an additional 50 years. Going from a six- to eight-month median survival to 50 years is just breathtaking.

JCI: Did you have any idea when you started this job that you were going to have to spend quite so much time on politics and advocacy?

Fauci: No. I think one of the best things I did was realize this is the terrain, so get used to it and get good at it. And I learned some fundamental principles. One of the first things is to understand the relationships between people in power: the Congressmen and -women, the Senators, the chairs of committees, and importantly, the Presidents of the United States. I never in my wildest dreams would have thought that I would become adviser to five separate Presidents.
You have to separate and understand the difference between politics and policy. Stay away from the politics and focus on the consistency of the relationship between science and policy. Also, it's very heady; it really feels good to get invited to the White House and to sit in the Oval Office and the Situation Room and the Roosevelt Room, and talk to Presidents. But you have to make sure you don't let that go to your head to the point of telling someone in power what you think they want to hear. You can do that and get away with it once or twice, but then people will lose respect for you. A wise friend said to me, "When you go into the White House, you should always tell yourself that this may be the last time that you ever go in there. Go in saying, 'I'm going to tell this person exactly what the evidence-based scientific truth is.' If they don't like it, and you don't get asked back, so be it. But the chances are that even if they don't like it, the word will be out that you speak truth."

JCI: Is it true that you were asked to be the Director of NIH twice?

Fauci: More than twice. Every time, I felt strongly that I had reached the point where the balance between being close to the science, being able to continue to do clinical medicine, and yet still having a broad and significant impact on policy was best balanced where I am now as the Director of NIAID.

I remember very clearly that once during the George H.W. Bush administration, I sat down with the President and in his wonderful way, he said, "I want you to be the NIH Director." And I said, "Mr. President, with all due respect, I think I can serve you and the country better if I stay where I am.” Because we were right in the evolution of the AIDS pandemic. And I said, "This is what I do, and what I do really well, and this is really what you want me for." And we talked about it a bit, and then at the end of it, I thought he was going to really blow me off and be very gruff about it, and he said, "You know, I respected you a lot before today, but now, I really respect you. So go back and do your thing." And as I walked out the door, his Chief of Staff (John Sununu) grabbed me by the arm, and he said, "You son of a bitch, nobody says no to the President." Both of us started laughing, and then that actually strengthened my relationship with George H.W. Bush because after that, he continued to call upon me and ask my advice about things. So, rather than being a negative, it turned out to actually be a positive.

\section{JCI: Do you sleep?}

Fauci: Ha! Very little. I've made a choice, and I made it with my eyes open. I have a lot of responsibilities. I do more things than any one person should do. I still do clinical medicine. I run a pretty good size lab. I'm the Director of a very large institute, and I like to get involved, and I do get involved in trying to help the field through policy by the kinds of things I do with Congress and with the administration.

JCI: Plus, any number of editorial boards, being editor of Harrison's Principles of Internal Medicine, committees, writing articles, giving interviews, and interfacing with the media. How do you balance it all, while remaining happily married?

Fauci: You balance it by deciding if you really want to do this. I work very hard. I work until late in the evening, go home, eat, and work some more. I work every weekend, all day Saturday, and part of Sunday. I've made some tough decisions my children grew up having dinner with my wife and I every night even though it was very late. My wife and I used to have some discussions about how healthy it was for a 12-year-old to eat dinner at $9 \mathrm{pm}$, but we came to the group decision that it was healthier for a 12-, 9-, and 6-yearold to have dinner with their father and mother every night at $9 \mathrm{pm}$ than it is to have them eat at 6:30 when their father wasn't there and their mother was doing something else.

JCI: Have you ever considered an occupation that was not a scientist or medical doctor?

Fauci: Not seriously. I think I could have thought about being a physician, and only a physician, because there's something about the patient-physician interaction that's almost in my DNA. So, I could see myself being a practicing physician and not a scientist. I can't see myself ever having been a scientist that wasn't a physician.

If I couldn't choose medicine or science, it would almost certainly be in the arena of teaching, perhaps Latin or English. I love to teach because I like to take complicated concepts and make them simple for someone to understand. There's a certain rush you get when someone is confused about something and you explain it in a way that they really can understand the concept.

\section{Ushma S. Neill}

